DOI: $10.31471 / 2415-3184-2019-1(19)-34-42$

\author{
М. М. Лагойда', О. С. Яремко \\ Л. М. Архипова ${ }^{2}$ \\ ${ }^{1}$ Мала академія наук Украӥни \\ ${ }^{2}$ Івано-Франківський національний \\ технічний університет нафти і газу
}

\title{
ТЕНДЕНЦІЇ ЧАСОВОГО РОЗПОДІЛУ КЛІМАТИЧНИХ ПОКАЗНИКІВ НА ТЕРИТОРІЇ ІВАНО-ФРАНКІВСЬКОЇ ОБЛАСТІ
}

Метою дослідження є встановлення тенденцій i закономірностей просторово-часового розподілу кліматичних показників на території Івано-Франківської області шляхом статистичної обробки матеріалів метеорологічних спостережень. За допомогою програмного продукту Caterpillar SSA 3.40 метод сингулярного спектрального аналізу був апробований для прогнозних моделей динаміки гідротермічного коефіцієнта по Івано-Франківській області й відхилення від норми сумарної річної кількості опадів та середньорічної температури повітря за даними метеостанцій Івано-Франківської області за період 1990-2018 рр. на прогнозну перспективу до $2028 \mathrm{p}$.

Новизна наукової роботи полягає в тому, що дістало подальшого розвитку дослідження тенденцій і закономірностей змін клімату для території Івано-Франківської області шляхом встановлення прогнозної динаміки показників температури та місячних сум опадів, що грунтується на обробці багаторічних матеріалів метеорологічних спостережень метеостанцій Яремче, Пожижевська, Коломия, Івано-Франківськ та Долина.

Побудовані методом сингуляторного спектрального аналізу прогнозні моделі відхилення від норми кліматичних показників на період до 2028 р. доводять, що глобальне потепління клімату для території Івано-Франківської області приведе до підвищення температурних показників, збільшення кількості опадів та зниження гідротермічного коефіцієнта. Гідротермічний показник має поступову тенденцію до зменшення, що підтверджує загальні кліматичні зміни в ІваноФранківській області. Однак значення ГТК на прогнозний період залишатимуться значно вищими від одиниці, отже, посухи Івано-Франківській області не загрожують.

Результати досліджень можуть бути використані для прогнозних оцінок змін кліматичних параметрів у межах області для прийняття рішень адаптації до глобальних кліматичних змін, у навчальному процесі.

Ключові слова: кліматичні зміни, прогнозні моделі, гідротермічний коефіцієнт.

Постановка проблеми. Дослідження питань глобальних змін клімату є актуальним на рівні одиниць адміністративного поділу для зменшення негативних наслідків. Предметом дослідження вибрано тенденції і закономірності змін кліматичних показників у межах Івано-Франківської області, зокрема просторово-часовий розподіл опадів та температури в області, територія якої належить до паводконебезпечних. Розподіл атмосферних опадів та температури повітря в межах області має специфічні особливості у зв'язку з наявністю рівнинної і гірської частин. Тому дослідження тенденцій прогнозних змін і закономірностей кліматичних характеристик на території Івано-Франківської області є актуальним науково-практичним завданням.

Аналіз останніх досліджень і публікацій. Підписання Рамкової Конвенції ООН про зміну клімату представниками 175 країн свідчить про те, що зміна клімату $є$ значною загрозою навколишньому середовищу та економічному розвитку. Дослідженню змін клімату присвячено велику кількість робіт науковців, однак локальні тенденції можуть відрізнятися від глобальних [1-4]. Аналіз попередніх досліджень дозволяє констатувати недостатню вивченість багаторічних змін клімату та його наслідків для Івано-Франківської області [4-6].

Постановка завдання. Метою дослідження $є$ встановлення тенденцій і закономірностей просторово-часового розподілу кліматичних показників на території Івано-Франківської області шляхом статистичної обробки матеріалів метеорологічних спостережень. Для досягнення мети ми визначили такі завдання: узагальнити наукові розвідки за темою дослідження; проаналізувати матеріали метеорологічних спостережень із метеостанцій Івано-Франківської області; провести їхню статистичну обробку з визначенням відхилень від норми показників температури та опадів, виконати часовий прогноз розподілу опадів, температури та гідротермічного коефіцієнта. 
Виклад основного матеріалу. Річний хід температур в Івано-Франківської області характеризується невисокими амплітудами в літні місяці і порівняно високими взимку. Вони також суттєво відрізняються в гірських районах і на рівнинах. Так, середні температури липня для Подільської і Передкарпатської частин області становлять $18-18,5^{\circ} \mathrm{C}$, а в масиві Чорногора, на висоті понад 1800 м, - від 9 до $11^{\circ} \mathrm{C}$. Тобто на кожні 100 м висоти температура знижується в середньому на $0,7^{\circ} \mathrm{C}$ [2]. У січні менша відмінність між середньомісячними температурами у горах і на рівнинах, відповідно $7-7,6^{\circ} \mathrm{C}$ і $4,5-5,0^{\circ} \mathrm{C}$ нижче від нуля [3].

Максимальні температури (понад $+38^{\circ} \mathrm{C}$ ) спостерігалися у східній частині області, зокрема, на метеорологічній станції в Коломиї. У горах найвища температура $+27{ }^{\circ} \mathrm{C}$ зафіксована на схилі Чорногірського хребта станцією Пожижевська (висота - 1450 м). Мінімальні температури для цієї ж метеорологічної станції становлять $--28^{\circ} \mathrm{C}$, а для Коломиї - $-36^{\circ} \mathrm{C}$ [2].

Амплітуда середніх температур на рівнинних територіях області, а отже, і ступінь континентальності повітря збільшується в напрямку на південний схід. У Карпатах континентальність згладжується і середні річні амплітуди температур не перевищують $21^{\circ} \mathrm{C}$ [3].

Для визначення особливостей просторово-часового розподілу опадів та температури на території Івано-Франківської області, проаналізовано дані з метеостанцій Коломия (297 м над рівнем моря), Яремче (531 м над рівнем моря), Пожижевська (1450,8 м над рівнем моря), ІваноФранківськ (280 м над рівнем моря) та Долина (470 м над рівнем моря).

Норма опадів на метеостанції Коломия (297 м) становить 699 мм. Ми проаналізували дані 3 метеостанції, розрахували відхилення від норми опадів і виявили тенденцію до підвищення річної кількості опадів (рис. 1). Протягом 1990-2018 pp. середньо-багаторічна кількість опадів збільшилась на 13 мм щодо норми. Найбільш посушливими були 1990, 2003 та 2011 роки, а найбільш вологими - 2001, 2008 та 2010 роки.

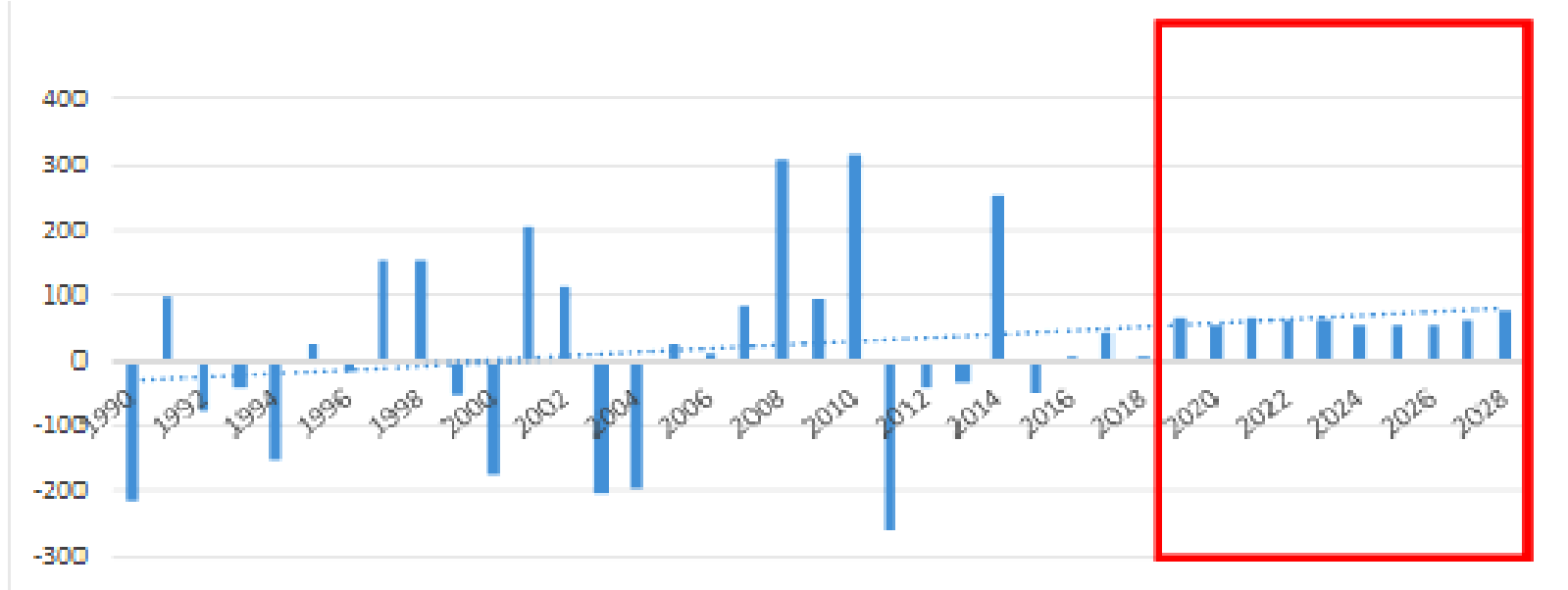

\section{Рис. 1. Прогнозна модель динаміки відхилення від норми сумарної річної кількості опадів (мм) для метеостанції Коломия до 2028 р.}

Щодо температури повітря, то норма для метеостанції Коломия становить $7,1^{\circ} \mathrm{C}$. Було також розраховано відхилення від температурної норми $\mathrm{i}$ виявлено тенденцію до підвищення температури. Протягом 1990-2018 pp. середньо-багаторічна температура збільшилась на $0,96^{\circ} \mathrm{C}$ відносно норми (рис. 2). У період з 1990 до 2018 рр. температура повітря була вища за норму всі роки, не враховуючи 1993 р. та 1996 р.

Норма опадів для метеостанції Яремче становить 931 мм. Було проаналізовано дані 3 метеостанції, розраховано відхилення від норми опадів і виявлено тенденцію до підвищення річної кількості опадів. Протягом багаторічного циклу середньо-багаторічна кількість опадів збільшилась на 69 мм відносно норми. Найбільш посушливими були 1990, 2000, 2012 та 2013 роки, а найбільш вологими - 1998, 2001, 2008 та 2010 роки.

Щодо температури повітря, то норма для метеостанції Яремче становить $6,9^{\circ} \mathrm{C}$. Було також розраховані відхилення від температурної норми і була виявлена тенденція до підвищення температури. Протягом 1990-2018 pp. середньо-багаторічна температура збільшилась на $1,11^{\circ} \mathrm{C}$ щодо норми. У період з 1990 до 2018 рр. майже кожного року (крім 1991 р., 1994 р., 1996 р., 1997 р.) температура повітря була вищою від норми. 


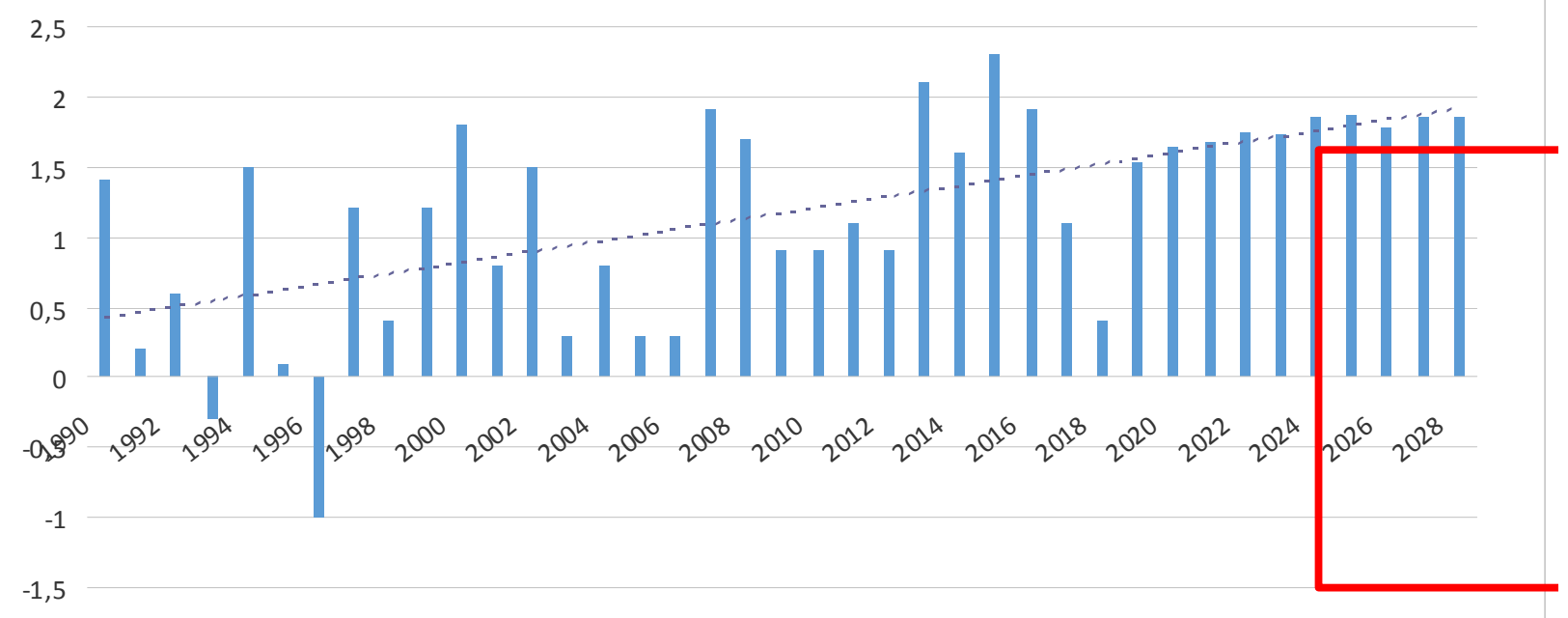

Рис. 2. Прогнозна модель динаміки відхилення від норми середньорічної температури для метеостанції Коломия до 2028 р.

Норма опадів для метеостанції Пожижевська становить 1423 мм. Було проаналізовано дані 3 метеостанції, розраховано відхилення від норми опадів і виявлено тенденцію до підвищення річної кількості опадів (рис. 3). Протягом багаторічного циклу середньо-багаторічна кількість опадів збільшилась на 68 мм щодо норми. Найбільш посушливими були 1990, 2000, 2003 та 2012 роки, а найбільш вологими - 1998, 2008, 2010 та 2017 роки.

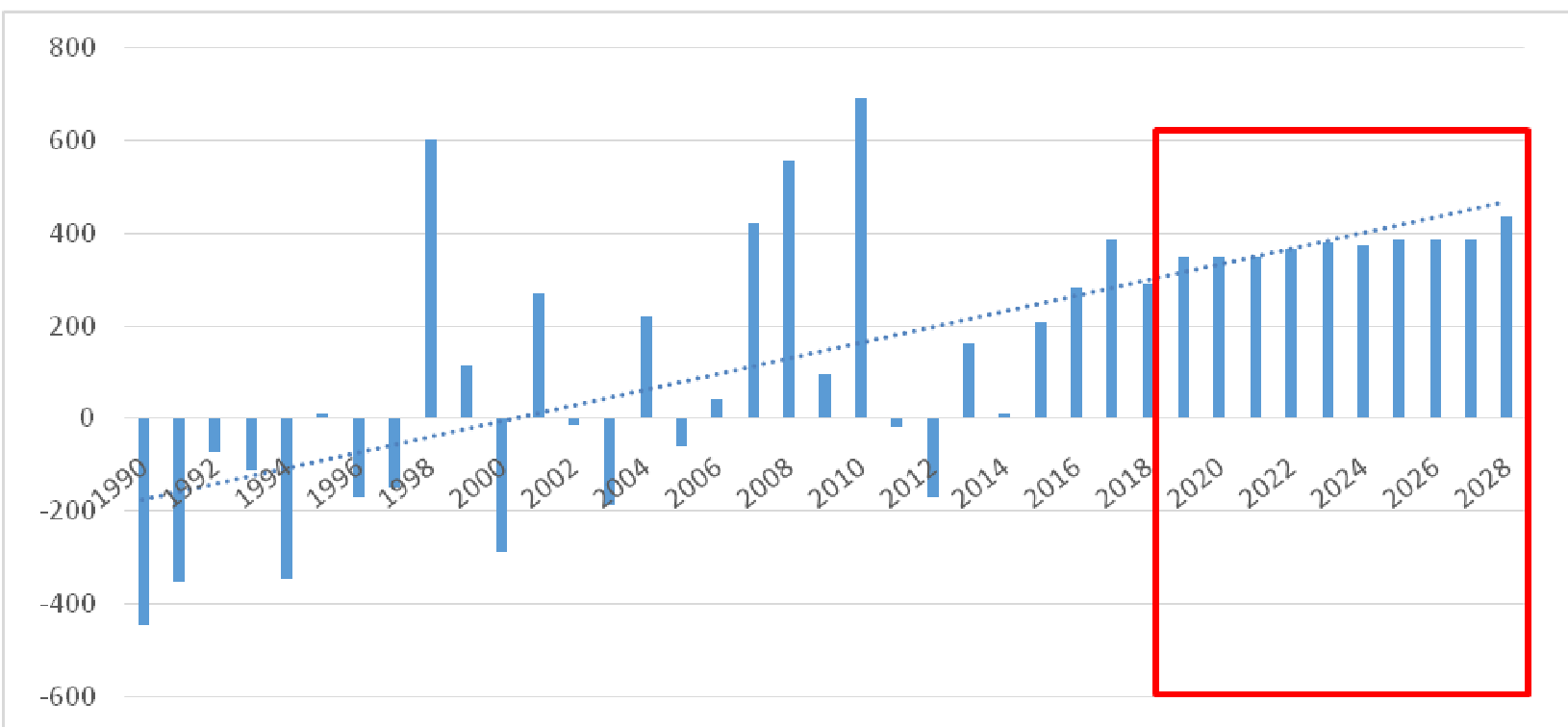

Рис. 3. Прогнозна модель динаміки відхилення від норми сумарної річної кількості опадів для метеостанції Пожижевська до 2028 р.

Щодо температури, то норма для метеостанції Пожижевська складає $2,7^{\circ} \mathrm{C}$. Були також розраховані відхилення від температурної норми і була виявлена тенденція до підвищення температури. Протягом багаторічного циклу середньо-багаторічна температура збільшилась на 0,82 ${ }^{\circ} \mathrm{C}$ щодо норми (рис. 4). У період за 1990-2018 роки найтеплішими були 2000, 2007, 2008, 2012, 2015 роки.

Норма опадів для метеостанції Івано-Франківськ становить 689 мм. Була виявлена тенденція до підвищення річної кількості опадів. Протягом багаторічного циклу середньо-багаторічна кількість опадів збільшилась на 5 мм щодо норми. Найбільш посушливими були 1990, 1994, 1995 та 2011 роки, а найбільш вологими - 1998, 2008, 2010 та 2016 роки.

Щодо температури, то норма температури складає $7,9^{\circ} \mathrm{C}$. Ми також розрахували відхилення від температурної норми і виявили тенденцію до підвищення температури. Протягом 19902018 рр. середньо-багаторічна температура збільшилась на $0,15^{\circ} \mathrm{C}$ щодо норми. У період за 1990 2018 роки найтеплішими були 2000, 2007, 2015 та 2016 роки. 
Норма опадів для метеостанції Долина становить 890 мм. Було проаналізовано дані 3 метеостанції, розраховано відхилення від норми опадів і виявлено тенденцію до підвищення річної кількості опадів. Протягом 1990-2018 рр. середньо-багаторічна кількість опадів збільшилась на 8 мм щодо норми. Найбільш посушливими були 1990, 1994, 2000 та 2003 роки, а найбільш вологими - 1998, 2001, 2008 та 2010 роки.

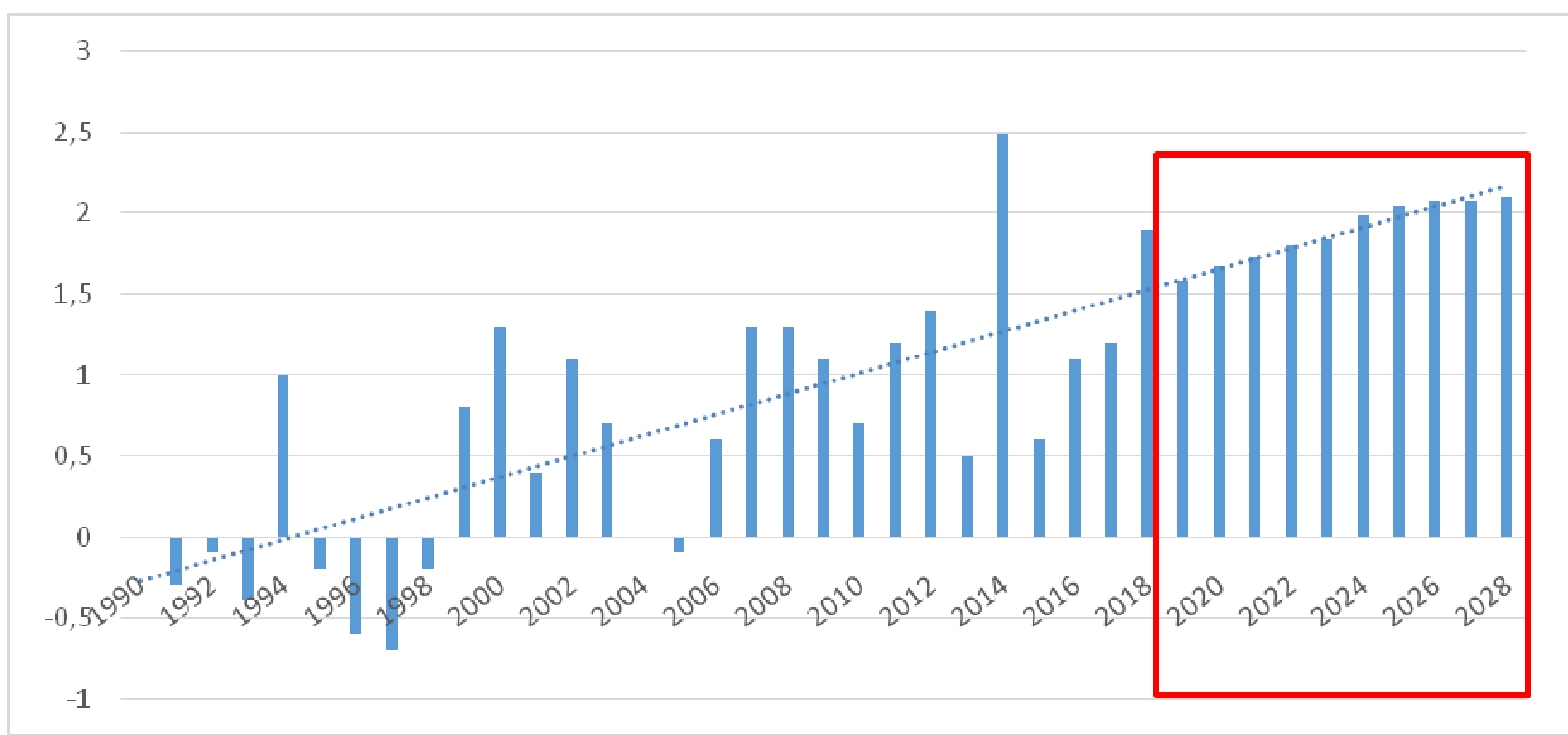

Рис. 4. Прогнозна модель динаміки відхилення від норми середньорічної температури для метеостанції Пожижевська до 2028 р.

Щодо температури, то норма температури складає $7,2^{\circ} \mathrm{C}$. Було проаналізовано дані 3 метеостанції, розраховано відхилення від норми температури і виявлено тенденцію до іiі підвищення. Протягом 1990-2018 pp. середньо-багаторічна температура збільшилась на 0,45 ${ }^{\circ} \mathrm{C}$ щодо норми. У період за 1990-2018 роки найтеплішими були 2000, 2007, 2015 та 2016 роки.

Отже, аналіз статистичних даних місячних і річних сум опадів та середньомісячних $\mathrm{i}$ середньорічних температур повітря за період 1990-2018 pp. 3 існуючих 5 метеостанцій ІваноФранківської області підтверджує глобальні кліматичні зміни, що проявляються у неухильному збільшенні середньорічної температури та средньобагаторічної кількості опадів.

Дослідження щодо підвищення температури повітря підтверджують відомі процеси зміни клімату у межах Європи.

Тенденцію щодо підвищення кількості опадів у межах Івано-Франківської області, на нашу думку, можна пояснити таким чином. Коефіцієнт зволоження на території Івано-Франківської області дорівнює або більший від одиниці. Із зростанням температури підвищується випаровування 3 підстильної поверхні, отже, збільшується вологовміст повітря, i, як наслідок, кількість опадів. Згідно з проведеними дослідженнями більший приріст опадів порівняно 3 нормою спостерігається в гірській місцевості, менший - у рівнинній.

Для прогнозування динаміки відхилення від норми сумарної річної кількості опадів по метеостанціях області було застосовано метод сингулярного спектрального аналізу Singular spectrum analysis (SSA), який покладений в основу програмного продукту Caterpillar SSA 3.40. Метод грунтується на дослідженні часового ряду методом головних компонент, дозволяє досліджувати структуру часового ряду, виділяти деякі його складники та прогнозувати як сам ряд, так і тенденції розвитку його складових. Метод поєднує в собі елементи класичного аналізу часових рядів, багатовимірної статистики, багатовимірної геометрії, динамічних систем та обробки сигналів. Цей метод широко застосовують для дослідження та прогнозування гідрометеорологічних часових рядів [4].

У межах проведеної наукової роботи за допомогою програмного продукту Caterpillar SSA 3.40 цей метод був апробований для прогнозних моделей динаміки відхилення від норми сумарної річної кількості опадів за даними метеостанцій Івано-Франківської області за період 1990-2018 рр. на прогнозну перспективу до 2028 р. Приклади подані на рис. 1, 3 для метеостанцій Пожижевська і Коломия.

Згідно з отриманими результатами, на всіх метеостанціях Івано-Франківської області (окрім 
метеостанції Яремче) спостерігається чітка позитивна тенденція змін у кількісному вираженні на прогнозований період відхилення від норми сумарної річної кількості опадів. На метеостанції Яремче спостерігається не зовсім чітка негативна тенденція змін у кількісному вираженні на прогнозований період відхилення від норми сумарної річної кількості опадів, проте відхилення від норми буде залишатися все ж таки додатним (рис. 5).

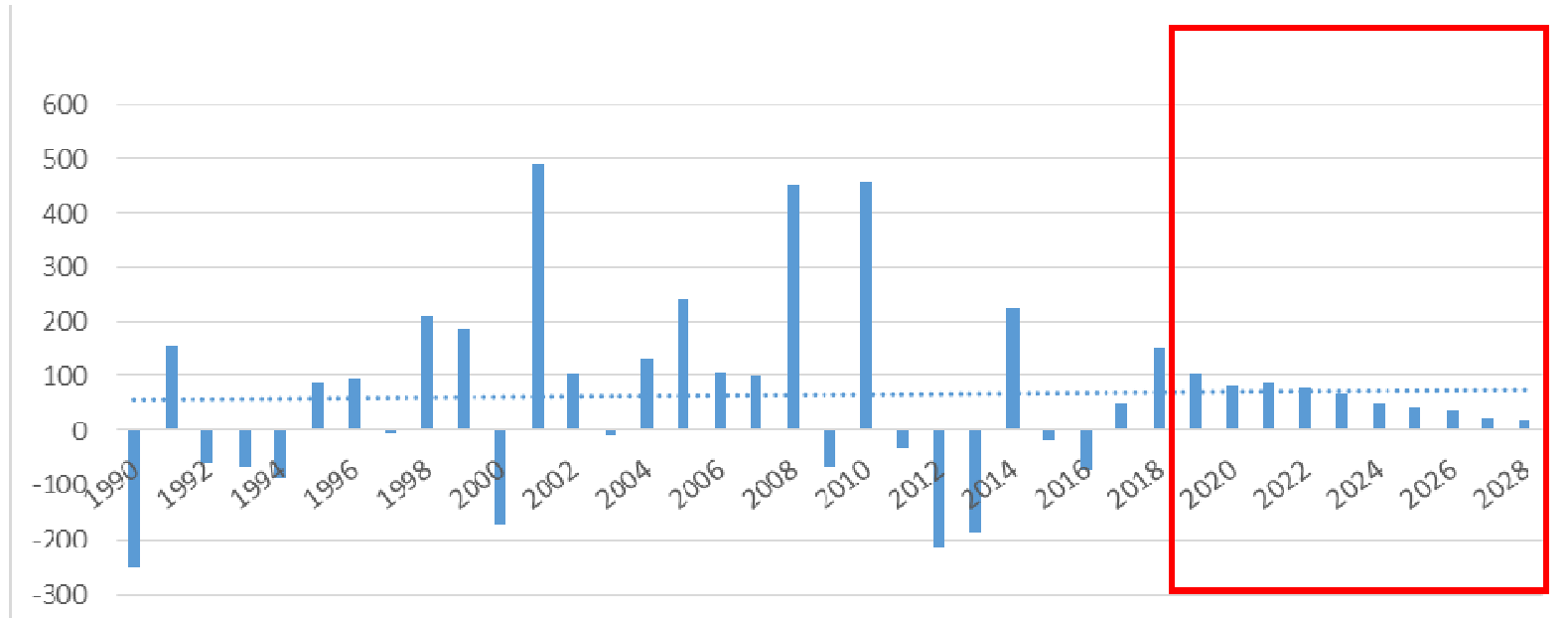

\section{Рис. 5. Прогнозна модель динаміки відхилення від норми сумарної річної кількості опадів для метеостанції Яремче до 2028 р.}

У межах проведеного наукового дослідження за допомогою програмного продукту Caterpillar SSA 3.40 цей метод був апробований також і для прогнозних моделей динаміки відхилення від норми середньорічної температури повітря за даними метеостанцій ІваноФранківської області за період 1990-2018 рр. на прогнозну перспективу до 2028 р. Приклади подані на рис. 2, 4 для метеостанцій Пожижевська і Коломия.

Згідно $з$ отриманими результатами, на всіх метеостанціях Івано-Франківської області спостерігається чітка позитивна тенденція змін у кількісному вираженні на прогнозований період відхилення від норми середньорічної температури повітря.

За допомогою гідротермічного коефіцієнту ми перевірили отримані прогнозні моделі.

Гідротермічний коефіцієнт (ГТК) увів Селянинов Г. Т. у 30-ті роки ХХ століття і став найпопулярнішим показником посух у вітчизняній агрометеорології та досі має широке застосування, незважаючи на появу нових індексів [5]. Гідротермічний коефіцієнт для окремих станцій (точок) обчислюють за формулою:

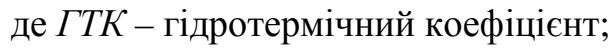

$$
\Gamma T K=\frac{\sum R}{0,1 \sum t},
$$

$\sum R$ - сума місячних опадів (у період вегетації);

$\sum t$ - сума температур повітря за період із середньодобовими температурами, вищими ніж $10^{\circ} \mathrm{C}$ (у межах того ж періоду вегетації).

Розрахунок ГТК обмежений вегетаційним періодом. Селянинов Г. Т. вважав, що сума температур повітря близька до випаровування з оптимально зволоженого поля і може братися за величину максимально можливого випаровування, тобто за випаровуваність. До того ж, у літні місяці суми температур повітря, поділені на 10, добре збігаються з сумами випаровуваності за місяць, виміряної евапорометром Вільда. ГТК характеризує не тільки припливну частину водного балансу - опади, але й непродуктивне витрачання вологи, пов'язане з випаровуваністю 3 поверхні грунту і рослин [5].

Аналіз просторово-часового розподілу ГТК для території України, виконаний у кліматичний період 1960-1990 рр., дозволив встановити середні характеристики цього параметра протягом вегетаційного сезону. Так, у роботі показано, що для середніх обласних значень ГТК характерно їхнє зменшення із заходу та північного заходу на південь і південний схід. У Поліссі ГТК змінюється від 1,6 (Житомирська область) до 1,2 (Сумська область). У Карпатах значення ГТК максимальні та досягають 2,5 . У західних областях Лісостепу ГТК коливається в межах 1,4-1,7, у східних районах ГТК зменшується до 1,0. У північному Степу значення ГТК дорівнюють 0,8-1,0. 
У південному Степу ГТК змінюється від 0,7 в Херсонській області до 0,9 в Миколаївській області [6].

Загалом на цей час використовуються такі критерії ГТК для визначення інтенсивності атмосферних посух в Україні: 0,7-1,0 - помірна посуха; 0,5-0,7 - сувора посуха; 0,3-0,5 - дуже сувора посуха [5].

У процесі аналізу структури агро-кліматичних ресурсів Івано-Франківщини було виділено два райони: гірський та рівнинний [6].

3 огляду на зазначене вище, ми вирішили спрогнозувати динаміку гідротермічного коефіцієнта для метеостанцій Івано-Франківськ та Долина, які уособлюють рівнинну та гірську частини області відповідно. Для вирішення цього завдання ми розрахували значення гідротермічного коефіцієнта для метеостанцій Івано-Франківськ і Долина та скористалися методом сингулярного спектрального аналізу. За допомогою програмного продукту Caterpillar SSA 3.40 цей метод був також апробований і для прогнозних моделей динаміки гідротермічного коефіцієнта за період 1990-2018 рр. на прогнозну перспективу до 2028 р. на території ІваноФранківської області (рис. 6, 7).

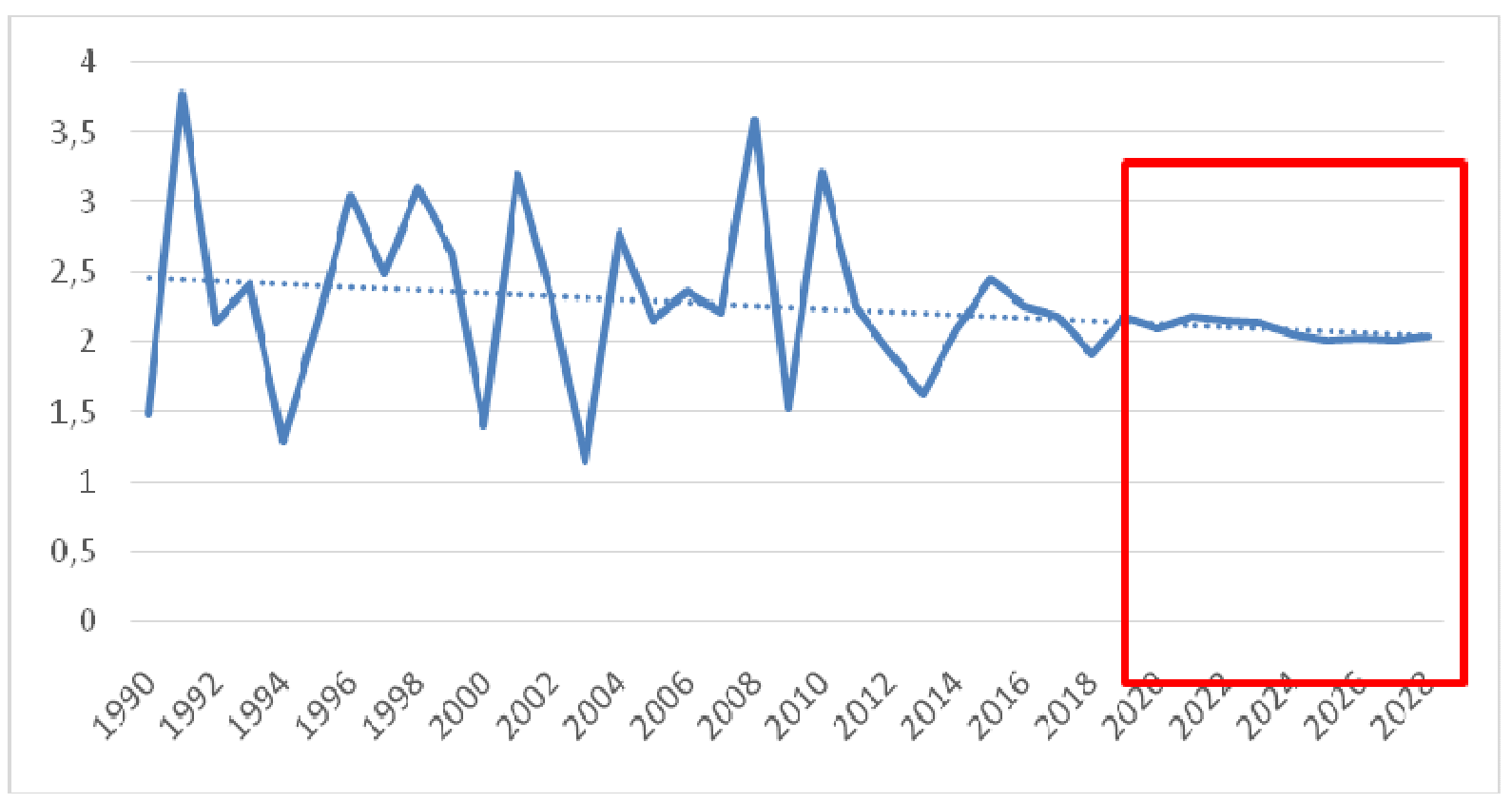

Рис. 6. Прогнозна модель гідротермічного коефіцієнта для гірської частини Івано-Франківської області

Отож у прогнозований період гідротермічний показник має поступову тенденцію до зменшення, що підтверджує загальні кліматичні зміни, пов'язані з глобальним потеплінням в Івано-Франківській області. Однак значення ГТК на прогнозний період залишатимуться значно вищими від одиниці, отже, посухи Івано-Франківській області не загрожують.

Загалом у прогнозований нами період гідротермічний коефіцієнт буде нижчим у рівнинному районі (Галицький, Городенківський, Калуський, Коломийський, Рогатинський, Снятинський, Тисменицький та Тлумацький райони), ніж у гірському (Богородчанський, Верховинський, Долинський, Косівський, Надвірнянський та Рожнятівський райони).

Висновки. У межах проведеного наукового дослідження за допомогою програмного продукту Caterpillar SSA 3.40 метод сингулярного спектрального аналізу був апробований для прогнозних моделей динаміки гідротермічного коефіцієнта по Івано-Франківській області та відхилення від норми сумарної річної кількості опадів та середньорічної температури повітря за даними метеостанцій Івано-Франківської області за період 1990-2018 pр. на прогнозну перспективу до 2028 р.

Гідротермічний показник має поступову тенденцію до зменшення, що підтверджує загальні кліматичні зміни, пов'язані з глобальним потеплінням в Івано-Франківській області. Однак значення ГТК на прогнозний період залишатимуться значно вищими від одиниці, отже, посухи Івано-Франківській області не загрожують. 


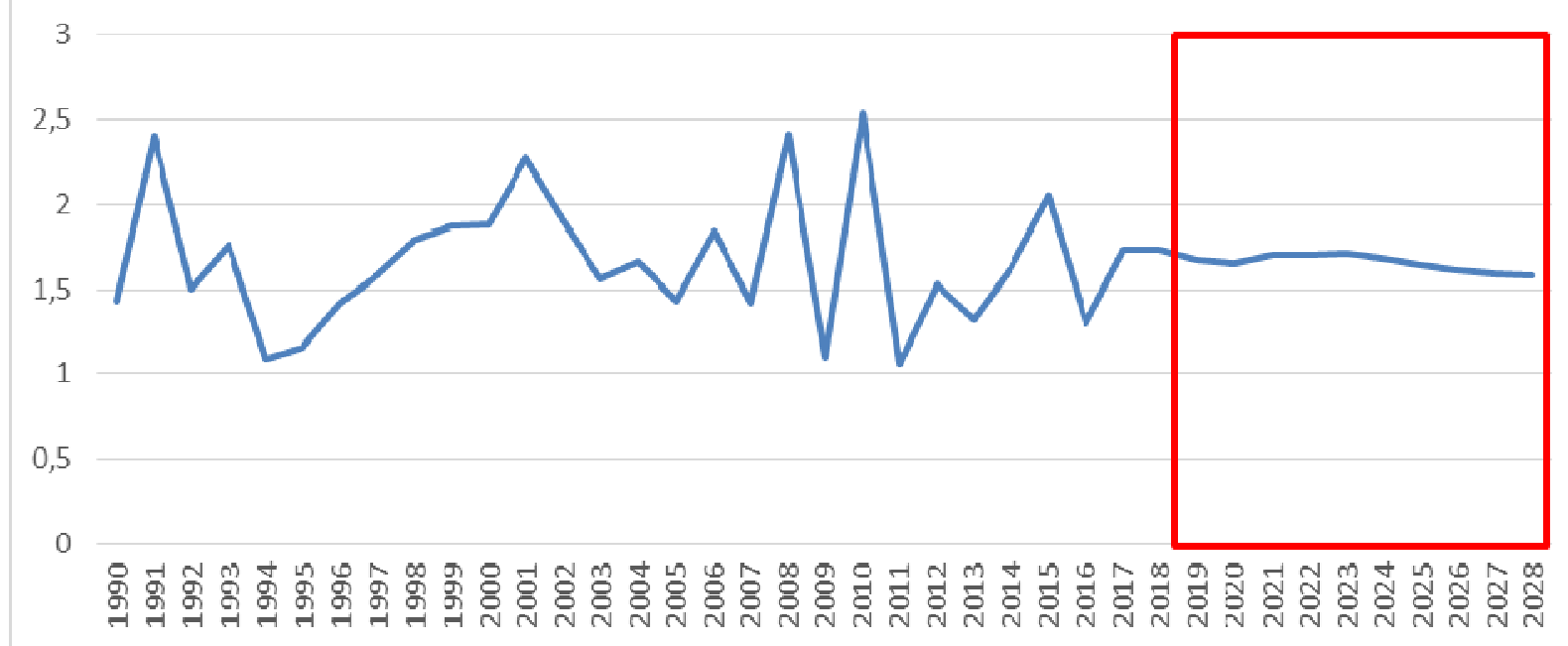

\section{Рис. 7. Прогнозна модель гідротермічного коефіціснта для рівнинної частини Івано-Франківської області}

Побудовані прогнозні моделі відхилення від норми кліматичних показників на період до 2028 р. доводять, що глобальне потепління клімату для території Івано-Франківської області приведе до підвищення температурних показників, збільшення кількості опадів та зниження гідротермічного коефіцієнта.

\section{Література}

1 Arkhypova L. M. Forecasting water bodies hydrological parameters using singular spectrum analysis/L. M. Arkhypova, S. V. Pernerovska // Scientific bulletin of National Mining University. Scientific and technical journal number. - 2015. - № 2 (146). - P. 45-50.

2 Cherenkova E. Drought and grain crop yields over the East European Plain under influence of quasibiennial oscillation of global atmospheric processes / E. Cherenkova, I. Semenova, M. Bardin, A. N. Zolotokrylin // 208 International Journal of Atmospheric Sciences. - 2015. - Vol. 2015, Article ID 932474. - 11 pages. DOI:10.1155/2015/932474.

3 Dai A. Drought under global warming: a review / A. Dai // Wiley Interdisciplinary Reviews: Climate Change. - 2011. - Vol. 2 (1). - P. 45-65.

4 Корчемлюк М. В. Екологічні наслідки глобальних кліматичних змін [Текст] / М. В. Корчемлюк, М. М. Приходько, Л. М. Архипова // Науковий вісник ІФНТУНГ : науковотехнічний журнал. - 2016. - № 1 (13). - С. 120-129.

5 Киналь О. Клімат східної частини Прут - Дністровського межиріччя (в межах Чернівецької області) [Текст] / О. Киналь // Науковий вісник Чернівецького університету. - 2006. № 305. - C. 197-205.

6 Karnieli A. Use of NDVI and land surface temperature for drought assessment: Merits and limitations / A. Karnieli, N. Agam, R.T. Pinker, M. Anderson [et al.] // J. Climate. - 2010. - Vol. 23. P. 618-633.

7 Корчемлюк М. В. Вплив змін клімату на водний режим гірської частини басейну р. Прут [Текст]/ М. В. Корчемлюк, М. М. Приходько, Л. М. Архипова // Проблеми геоморфології і палеогеографії Українських Карпат і прилеглих територій - Львів : ЛНУ імені Івана Франка, 2016. - Вип. 1 (6). - С.118-128.

8 Мартазінова В. Зміни в кліматі України [Текст] / В. Мартазінова // Географія та основи економіки в школі. - 2002. - № 1 (25). - С. 31-33.

9 Hryniuk V. I. Regularity of effects of climatic changes on quality indicators of surface water of the Dnister basin /V. I. Hryniuk, L. M. Arkhypova// Naukovyi Visnyk NHU. - 2018. - № 3 (165). P. $125-133$

10 Семенова, I. Г. Синоптичні та кліматичні умови формування посух в Україні [Текст] : монографія / Одеський державний екологічний університет. - Х. : ФОП Панов А. М., 2017. - 236 с.

11 Singh R.P. Vegetation and temperature condition indices from NOAA AVHRR data for drought monitoring over India / R.P. Singh, S. Roy, F. Kogan // Int. J. Remote Sensing. - 2003. - Vol. 24, No. 22. - P. 4393-4402. 
12 Semenova I. G. Regional atmospheric blocking in the drought periods in Ukraine / G. Semenova // Journal of Earth Science and Engineering. - 2013. - Vol. 3 (5). - P. 341-348.

\author{
M. Lahoida ${ }^{1}$, O. Yaremko ${ }^{1}$, L. Arkhypova ${ }^{2}$ \\ ${ }^{1}$ Small Academy of Sciences of Ukraine \\ ${ }^{2}$ Ivano-Frankivsk National \\ Technical University of Oil and Gas
}

\title{
TENDENCIES OF THE TIME DISTRIBUTION OF CLIMATIC INDICATORS IN IVANO-FRANKIVSK OBLAST
}

The purpose of the study is to define the trends and regularities of the spatial and temporal distribution of climatic indicators in Ivano-Frankivsk oblast by means of statistical processing of the meteorological observations data. With the help of the software product Caterpillar SSA 3.40, the singular spectrum analysis method was tested for the forecasting models of the hydrothermal coefficient dynamics in Ivano-Frankivsk oblast and the deviations of the total annual amount of precipitation and the average annual air temperature according to the data of the meteorological stations of Ivano-Frankivsk oblast for the period of 1990-2018 and for the forecasting perspective up to 2028.

The novelty of research work is that it has further developed the research of trends and regularities of climate changes for the territory of Ivano-Frankivsk oblast by means of defining the forecasting dynamics of temperature and monthly rainfall data, based on the processing of multi-year meteorological observations of the meteorological stations in Yaremche, Pozhyzhevska, Kolomyia, Ivano-Frankivsk, and Dolyna.

The forecasting models of deviations of climatic indicators for the period up to 2028, developed according to the singular spectrum analysis method, prove that the global warming on the territory of Ivano-Frankivsk oblast will increase the temperature indexes and the amount of precipitation and reduce the hydrothermal coefficient. The hydrothermal coefficient has a gradual tendency to decrease, which substantiates the general climate changes in Ivano-Frankivsk oblast. However, the values of the hydrothermal coefficient in the forecast period will remain much higher, and therefore droughts do not threaten Ivano-Frankivsk oblast.

The research results can be used for the estimations of future changes in climate parameters within the region in order to make decisions for adaptation to global climate changes and in the educational process.

Key words: climate changes, forecasting models, hydrothermal coefficient.

\section{References}

1 Arkhypova L. M. Forecasting water bodies hydrological parameters using singular spectrum analysis/L. M. Arkhypova, S.V. Pernerovska // Scientific bulletin of National Mining University. Scientific and technical journal number. - 2015. - № 2 (146). - P.45-50.

2 Cherenkova E. Drought and grain crop yields over the East European Plain under influence of quasibiennial oscillation of global atmospheric processes / E. Cherenkova, I. Semenova, M. Bardin, A. N. Zolotokrylin // 208 International Journal of Atmospheric Sciences. - 2015. - Vol. 2015, Article ID 932474. - 11 pages. DOI:10.1155/2015/932474.

3 Dai A. Drought under global warming: a review / A. Dai // Wiley Interdisciplinary Reviews: Climate Change. - 2011. - Vol. 2 (1). - P. 45-65.

4 Korchemliuk M. V. Ekolohichni naslidky hlobalnykh klimatychnykh zmin [Tekst]/ M.V.Korchemliuk, M.M.Prykhodko, L.M. Arkhypova // Naukovyi visnyk IFNTUNH: naukovotekhnichnyi zhurnal. - 2016. - № 1 (13). - P. 120-129.

5 Kynal O. Klimat skhidnoi chastyny Prut - Dnistrovskoho mezhyrichchia (v mezhakh Chernivetskoi oblasti) [Tekst] / O. Kynal // Naukovyi visnyk Chernivetskoho universytetu. - 2006. № 305. - P.197-205.

6 Karnieli A. Use of NDVI and land surface temperature for drought assessment: Merits and limitations / A. Karnieli, N. Agam, R.T. Pinker, M. Anderson [et al.] // J. Climate. - 2010. - Vol. 23. P. 618-633.

7 Korchemliuk M.V. Vplyv zmin klimatu na vodnyi rezhym hirskoi chastyny baseinu r. Prut [Tekst] / M. V. Korchemliuk, M. M.P rykhodko, L. M. Arkhypova // Problemy heomorfolohii i 
paleoheohrafii Ukrainskykh Karpat i prylehlykh terytorii - Lviv: LNU imeni Ivana Franka, 2016. Vyp. 1(6). - P.118-128

8 Martazinova V. Zminy v klimati Ukrainy [Tekst] / V. Martazinova // Heohrafiia ta osnovy ekonomiky v shkoli. - 2002. - № 1 (25). - P.31-33.

9 Hryniuk V. I. Regularity of effects of climatic changes on quality indicators of surface water of the Dnister basin /V.I. Hryniuk, L. M. Arkhypova// Naukovyi Visnyk NHU. - 2018. - № 3 (165). P.125-133

10 Semenova, I. H. Synoptychni ta klimatychni umovy formuvannia posukh v Ukraini [Tekst] : monohrafiia / Odeskyi derzhavnyi ekolohichnyi universytet. - Kh. : FOP Panov A.M., 2017. - 236 p.

11 Singh R.P. Vegetation and temperature condition indices from NOAA AVHRR data for drought monitoring over India / R.P. Singh, S. Roy, F. Kogan // Int. J. Remote Sensing. - 2003. - Vol. 24, No. 22. - P. 4393- 4402.

12 Semenova I.G. Regional atmospheric blocking in the drought periods in Ukraine / I.G. Semenova // Journal of Earth Science and Engineering. - 2013. - Vol. 3 (5). - P. 341-348.

Надійшла до редакиії 25 квітня 2019 р. 